\title{
Umbrella Supervision and the Role of the Central Bank
}




\title{
Umbrella Supervision and the Role of the Central Bank
}

by Joseph G. Haubrich and James B. Thomson

\begin{abstract}
Deregulation and financial consolidation have led to the development of financial holding companiesallowing commercial banking, insurance, investment banking, and other financial activities to be conducted under the same corporate umbrella — and the Federal Reserve has been named supervisor of the consolidated enterprise. This Policy Discussion Paper will show that there likely are economies of scope between the Fed's inherent central-banking responsibilities and those of an umbrella supervisor and that these duel roles benefit both the Fed and functional regulators.
\end{abstract}

Joseph $\mathrm{G}$. Haubrich is an economic advisor at the Federal Reserve Bank of Cleveland. James B. Thomson is a vice president and an economist at the Bank.

Materials may be reprinted if the source is credited. Please send copies of reprinted materials to the editor.

We invite questions, comments, and suggestions. E-mail us at editor@clev.frb.org.

POLICY DISCUSSION PAPERS

Policy Discussion Papers are published by the Research Department of the Federal Reserve

Bank of Cleveland. To receive copies or to be placed on the mailing list, e-mail your request

Policy Discussion Papers are available electronically through the Cleveland Fed's site on the World Wide Web: www.clevelandfed.org/Research.

Views stated in Policy Discussion Papers are those of the authors and not necessarily those of the Federal Reserve Bank of Cleveland or of the Board of Governors of the Federal Reserve System. 


\section{Introduction}

The specific roles and responsibilities of central banks vary widely, even among developed nations. For instance, the Federal Reserve System is a major provider of interbank settlement services and an interbank check-collection system, as well as payments services, which operate retail and wholesale wiretransfer systems. The Bank of Canada, on the other hand, is limited to providing interbank settlement services, and the Bank of England is not a bank supervisor at all. However, despite differences in institutional structure and in formal responsibilities, central banks all share three common objectives: (1) to ensure that the conduct of monetary policy is consistent with maximizing social welfare. (Increasingly, methods such as promoting price stability are seen as the way to achieve this objective); (2) to maximize social welfare by promoting financial-system stability, and (3) to provide for and foster efficient and stable payments systems. ${ }^{1}$

Green and Todd (2001) provide an economic analysis of central-banking activities with a focus on what they deem essential central-banking functions of the Federal Reserve System, specifically examining its role in the payments system. Green and Todd argue that the fundamental role of the central bank in the payments system is to supply liquidity and settlement services - that is, to provide a balance sheet where payment providers can settle their accounts with each other. The central bank provides liquidity through intra- and inter-day lending to assure the stability and efficiency of the payments system. These authors then argue that other Federal Reserve payments functions such as check processing and clearing and operation of retail and wholesale wire-transfer systems are not essential central-banking functions. Green and Todd conclude that in the absence of adequate economies of scope between the Fed's payments-system operations and its central-banking role, the Fed should be relieved from the provision of payments services. (It is worth noting that the Congress vested the Fed with an operational role in the payments system not because of perceptions of market failure in the payments system —although the same cannot be said for the discount window—but rather as a conscious attempt to ensure the viability of the Reserve Banks [Stevens 1996].)

Using the framework of Green and Todd, we will examine whether an economic case can be made for vesting the Federal Reserve with the role of umbrella supervisor of financial holding companies. Unlike Green and Todd who find no compelling economic rationale for continued participation of the Federal Reserve as a payments-system operator, we will show that there likely are economies of scope between the Fed's inherent central-banking responsibilities and those of an umbrella supervisor.

In response to the panic of 1907, the National Monetary Commission was formed to study the United States's financial system and to propose reforms to the monetary system as embodied by the national banking system. The National Monetary Commission report was followed by the creation of the Federal Reserve System whose duties are

To provide for the establishment of Federal reserve banks, to furnish an elastic currency, to afford means of rediscounting commercial paper, to establish a more effective supervision of banking in the United States, and for other purposes. ${ }^{2}$

This act is generally known by its short title, the Federal Reserve Act of 1913. It is clear from the original Federal Reserve Act and subsequent revisions thereto that the Federal Reserve Banks, through their discount windows, were to function as liquidity facilities to the banking system and lender of last resort
1. GBLA formally added protecting the domestic and international payments systems as a role for the umbrella supervisor of financial holding companies (Macey and others 2001).
2. 12 USC; ch. 6,38 Stat. 251 (December 23, 1913). 
to the financial system. ${ }^{3}$ Complementary to the discount window is the use of open market operations to inject liquidity into the financial system in response to external shocks. ${ }^{4}$

Interestingly, while one purpose of the 1913 legislation was to provide for more effective supervision of banking in the United States, the Congress did not vest the Fed with banking supervision and examination authority until 1917.5 Prior to this, Fed member banks were supervised by the Office of the Comptroller of the Currency (OCC) — extending the OCC's supervisory authority to state-chartered banks that joined the Federal Reserve System. Apparently, OCC oversight was seen as sufficient disincentive for state banks to join the System, resulting in Congressional revision of the Federal Reserve Act to provide for Federal Reserve supervision of state-member banks. ${ }^{6}$ Moreover, while subsequent legislation has added to the Federal Reserve's supervisory and regulatory responsibilities, it is not clear if these additional duties are economically justified along the lines of the Green and Todd criteria.

There are three sets of arguments that attempt to justify a bank supervisory role for the Fed. The first involves Reserve Banks' exposure to loss through their discount-window operations and paymentssystem guarantees. The second is related to financial-system stability and the potential for systemic banking problems. The depository-institutions sector of the financial system is particularly important to the central bank because it is the core of the transmission mechanism for monetary policy (in that most monetary policy actions are aimed at setting the price of quantity of reserves in the banking system). Moreover, banks as relationship lenders play an important role in credit allocation. A third set of arguments centers on the role of banks in the payments system. Clearing and settlement services provided by depository institutions are a crucial part of the payments system and, for this reason, central banks have a vested interest in banking-system stability as a means for promoting an efficient and stable payments system. ${ }^{7}$

While a healthy depository-institutions sector (and financial system) is necessary for the central bank to effectively perform its functions, it does not guarantee an active role for the central bank as supervisor of financial institutions or as a payments-system provider. In order to guarantee an active role, the timely flow of information on depository institutions to the central bank, some of which can only be collected and assembled as part of ongoing inspections of financial firms and routine regulatory reporting, is required. Access to such information does not require the central bank to be a direct supervisor, only that a mechanism exist for the central bank to acquire the information it needs from the existing supervisory agency(ies). On the surface, there appears to be no reason why the Fed could not, for instance, rely on information provided by the OCC or Federal Deposit Insurance Corporation (FDIC) to determine a banking institution's eligibility for certain discount-window-lending programs; as long as the central bank can inspect and perfect liens on collateral, the risks of lending are not sufficient to warrant more than a backup examination authority. ${ }^{8}$

However, the ability of the central bank to receive information from functional regulators does not in and of itself suggest that this arrangement is efficient. To be efficient, the functional regulator must collect the information that the central bank requires, or the information must be collected more efficiently by the regulator than by the central bank. Proponents of housing the bank-supervision function (or even broader financial-services supervision) within the central bank point out the importance of attracting and retaining qualified staff whose expertise and skills are needed to distinguish what information is useful and to evaluate this information once collected. It is not clear why a central bank would
3. The importance of central-bank liquidity facilities for financial and economic stability was discussed at length by Bagehot (1874). Bagehot described the role of the lender-of-last-resort function in financial-system stability. In this seminal work, Bagehot lays the foundation for the difference between financial stability and economic stability - a theory, later articulated by Bernanke and Gertler (1990) and other contemporary economists, commonly referred to as the "credit view."

4. This is the case whether the shocks emanate from the collapse of a large hedge fund, a foreign banking crisis, new or renewed foreign conflicts, terrorist activities, or other events that cause disruptions in financial markets and increase investor demand for liquidity.

5. 12 USC 32. As amended by act of June 21, 1917 (40 Stat. 232).

6. For discussions of these issues, see Haubrich and Santos (2003), Goodhart (2000), and GAO (2004).

7. In many countries, including the United States, depository institutions are the only private-sector entities allowed to have accounts with the central bank, and thus the majority of payments flow through the depository-institutions sector.

8. With a few exceptions, daylight overdrafts of reserve accounts are not collateralized and hence, the Fed extends unsecured intra-day credit essentially by guaranteeing finality of payments on its gross settlement system. There is no reason why collateral arrangements could not be established to protect the Reserve Banks from loss in the intraday credit market; therefore exposure to risk intraday is not a compelling argument for Fed supervision of banks and thrifts. 
have more trouble than a stand-alone regulatory agency attracting and retaining researchers and analysts capable of providing informed analysis of the financial sector. 9 However, the central bank would need to develop and retain a large staff of researchers and analysts whose functions overlap those of staff at the supervisory agency, thereby reducing the benefits of consolidating information collection with the examination function, possibly to the point where the net social benefits of consolidation are essentially zero.

\section{Information, Macroprudential Risks, and Umbrella Supervision}

The Federal Reserve's mandate for umbrella supervision of financial holding companies is aimed at two interconnected goals. As a safety and soundness regulator, the Federal Reserve is charged with understanding and examining holding companies, then enforcing the appropriate regulation. From the central-bank standpoint, the Federal Reserve needs to understand risk at the holding-company level to accomplish its goals in monetary policy and payment-systems oversight - this information and experience is crucial to its role as lender of last resort. The current practice of umbrella supervision falls short of these goals, and the problems are both conceptual and practical.

Conceptually, most holding-company regulation and regulatory guidance do not properly distinguish between social and individual risk. Regulation exists because, even when a bank is accurately assessing and managing its risk, it does not take the social externalities into account. The optimal amount (and type) of risk from the firm's perspective is not always the optimal amount from society's perspective. The Fed's approach to supervision needs to better incorporate this concept by explicitly acknowledging the need for this information.

From a practical standpoint, umbrella supervision also falls short, as the Federal Reserve's experience as a bank and bank-holding-company regulator is not sufficient enough for it to fully understand or supervise risk at the holding-company level of diversified financial-holding companies. The necessary cooperation with the functional supervisors (OCC, Securities \& Exchange Commission, state insurance commissioners) still needs to be worked out. To effectively perform the role of umbrella supervisor, the Federal Reserve will most likely have to expand its expertise into new areas to evaluate risk at the holding-company level. It remains unclear if appropriate risks are being examined, and there are few comprehensive quality measures or other benchmarks to assess the quality of current financial-holdingcompany umbrella supervision.

\section{Information Consolidation in a Competitive Regulatory Environment}

Goodhart (2000) contends that the common interests of the central bank and the financial-services regulator will ensure that the central bank has access to whatever information it needs to perform its functions. However, Goodhart's conclusions are based on an institutional structure where all financialservices regulation is housed in a single government agency — not like the current patchwork quilt of specialized industry regulators, and even competing regulators, within an industry. That is why, even if Goodhart's conjecture holds for the United States, some entity will need to collect and consolidate information produced by the industry regulators. Information consolidation does not require consolidation of financial supervision and, in fact, the U.S. Congress purposely rejected this approach in the 1999 Gramm-Leach-Bliley Act (GLBA). In lieu of intra- and inter-industry consolidation of regulatory bodies, GLBA adds an umbrella supervisor for financial holding companies to the mix. 
It is notable that GLBA mandates the holding-company structure for financial-industry consolidation-more specifically, the integration or reintegration of commercial banking with investment banking and insurance activities — and retains special industry regulators. Moreover, GLBA does not consolidate federal regulators of a single industry, even stopping short of consolidating the two depository-institution regulators under the U.S. Treasury Department. Instead, the Congress deliberately chooses to retain the competitive regulatory structure in this financial-market-reforms bill, and GLBA establishes that line of business, not organizational structure, determines who regulates an entity. ${ }^{10}$ For instance, the SEC is the primary regulator whether a securities firm is a stand-alone company or the subsidiary of a financialholding company.

Regardless the reason-Congressional acknowledgement of either the benefits of preserving existing regulatory agencies and reporting relationships or the grizzly realities of entrenched turf interests of incumbent regulatory agencies-functional regulation with consolidated supervision of the parent holding company is the model that was adopted in the United States. The role of the umbrella supervisor is to piece together a consolidated picture of the financial holding company's risks —including management's ability to understand and manage those risks. In other words, the umbrella supervisor is charged with producing a comprehensive picture of an institution as the collection of its parts, leaving the regulation and examination of each holding-company subsidiary to its functional regulator.

To illustrate how a functional regulator's assessment of the risks of a financial-holding company's subsidiary may not reflect the true risk of the subsidiary in the context of the entire company, consider Seven Blind Mice, a children's book based on an old Indian parable. ${ }^{11}$ In the story, the seven blind mice visit an elephant. The first six explore the part of the elephant they happen upon first, and each declares that he has discovered either a pillar, a snake, a cliff, a spear, a fan, or a rope. Only the seventh mouse, who explores the whole of the animal and collects all of the necessary information, is able to discern that it is an elephant. As in this story, it is not just the parts but how they fit together that give us the true profile of the risks of a financial-holding company.

To further stress the importance of producing a comprehensive picture, consider the Butcher banks. ${ }^{12}$ The Butcher brothers, Jake and C.H. Jr., owned or controlled approximately 40 depository institutions between them. Through what was known as chain banking, the Butchers' holdings included depository institutions in two FDIC jurisdictions and three Federal Reserve Districts. Unlike a bankholding company, this chain of commonly held institutions was not supervised on a consolidated basis. Depending on location, charter, and Federal Reserve membership status, examination of each separate chain-banking unit fell to one of the seven bank-thrift regulatory agencies involved, making it difficult for any single examination agency to detect systemwide problems. The lack of a comprehensive examination of their entire empire allowed the Butcher banks to hide asset-quality problems by shifting problem loans from one bank to another. Only after the FDIC conducted simultaneous examinations of all the major Butcher-affiliated banks were the asset-quality problems detected, leading to the closing of eight Butcher-affiliated banks in 1983 with losses to the FDIC of nearly \$383 million.

Increasingly, corporate separateness afforded by the holding-company structure is more relevant as a legal construct and less so an economic and business reality. New regulations such as Basel II capital requirements and Federal Reserve SR99-18 have further nudged banks and their parent holding companies toward organizing their risk-management and economic-capital-allocation plans according to 
lines of business, not legal entities. Moreover, the oversight responsibilities of senior management and boards of directors place an additional burden on risk management - the need to aggregate each type of risk to the corporate level so that risk limits and controls can be established. Hence, the need for aggregated risk information, coupled with economies of scale in information storage, retrieval, and processing, have reinforced the trend toward the adoption of enterprisewide risk management by diversified financial firms, including financial holding companies. ${ }^{13}$ Enterprisewide risk management is complementary to and leverages off risk management at the entity or business-line level. Functional regulators provide an important level of review of risk-management systems at the legal entity level, but they cannot, by design, adequately assess the enterprisewide risk-management efforts, particularly when this function is housed in the parent company. This can only be done effectively by a supervisor with the authority to look at the consolidated organization, e.g., either a consolidated regulatory agency like the Financial Services Authority in Great Britain or an umbrella supervisor.

\section{Umbrella Supervision and the Central Bank}

As with any financial-services-firm supervisor, the umbrella supervisor is required to be independent from partisan politics and the congressional appropriations process. ${ }^{14}$ Moreover, the umbrella supervisor must have sufficient stature in financial markets in order to attract and retain qualified staff. It is unlikely that a stand-alone agency, even in the broad and deep financial markets of the United States, would meet both of the above conditions, for how would such an entity be funded other than by congressional appropriations? After all, by design, the umbrella supervisor would conduct few, if any, examinations, so there would be no exam fees to rely on and, unlike the Fed and the FDIC, there would be no portfolio of government securities from which earnings could be used to support its operation. Hence, the umbrella-supervisory function would need to be housed in an existing agency, a new financial-regulatory agency, or the central bank.

Why might the Federal Reserve be a natural choice to be the umbrella supervisor? The short answer-because Congress delegated the role to the Fed in GLBA, and it is a natural extension of the Fed's role as regulator of bank holding companies_-is an unsatisfying response, providing no explanation why the central bank is a better choice for this role than a federal bank regulatory agency or even the Securities and Exchange Commission. However, an economic case can be made for the housing of the umbrella-supervisory function at the Fed. First, the Fed's responsibility to manage macroprudential risks-including concerns for financial stability and the integrity of the payments systemsuggests that there may be economies of scope between central-banking functions and umbrella supervision. In other words, the information the Fed needs to carry out its mission includes financialmarket and financial-firm information that an umbrella supervisor would collect and consolidate. In addition, the existence of the Federal Reserve is not contingent on its role as a functional supervisor. Consequently, any conflicts of interest between an agency's role as a functional supervisor and its role as umbrella supervisor should be less at the central bank. ${ }^{15}$ This, in turn, should facilitate cooperation between the umbrella-supervisory agency and functional regulators as it lessens the changes for turf struggles.

For a discussion of enterprisewide risk management in banking companies, see Bies (2004a, 2004b).

14. One has to look no further than the Office of Federal Housing Enterprise Oversight to see how dependence on Congressional appropriations to fund operations can interfere with the independence of a regulatory agency and hinder its ability to carry out its mission. 


\section{Economies of Scope between Natural Central-Banking Functions and Umbrella Supervision}

As mentioned earlier, one set of reasons for making the central bank the umbrella supervisor for the financial system involves economies of scope between the key central-bank functions and the functions of umbrella supervision; there are benefits to the central-bank functions that stem from umbrella supervision and vice versa. The combination raises an important question, however: How can umbrella supervision be structured to maximize these benefits while minimizing the downside brought on by multiple competing objectives?16

From the standpoint of monetary- and macroeconomic-stabilization policy, supervision aids the central bank's functions because it gives the central bank useful information. Knowledge of the state and health of the banking system can improve both analysis and forecasting. Indeed, Peek, Rosengren, and Tootell (1999) show how adding the Federal Reserve's confidential composite examination ratings to forecasting models leads to substantially more accurate predictions - on the order of half of a percentage point in the unemployment rate. ${ }^{17}$

It might be possible for the OCC or the FDIC to pass on confidential data (including ratings) to the central bank, but that may not be enough. It is not merely a question of the faster and better access that comes from creating the information in-house; Peek and others argue that the information used, and therefore collected, by a pure banking supervisor will never be quite the same as that preferred by a macroeconomic policymaker. Those charged with prudential supervision-concerned with the health of a particular institution or industry-will naturally have a different perspective on what data need to be reported than an economist charged with macroeconomic stability. For instance, the quarterly data reported to bank regulators are useful for determining the risk of a particular bank or thrift, but are of marginal value in understanding how an increase in interest rates will impact bank capital and bank lending (the economic-policy perspective). Over time, the value of the information collected would likely decline, and, similarly, reduced experience with the data may reduce the central bank's ability to understand the nuances.

But it is not just a matter of timely information or improved forecasts that make the Fed the best choice for supervisor. Since policymakers also need to know about the transmission mechanism of monetary policy — and the interest rates directly controlled by the Central Bank are connected to the rest of the economy via banks and the financial system - involvement with supervision provides a deep understanding of how banks and markets will react to monetary policy. This information is not always readily available from written reports, even when freely shared by other organizations. Effective decisionmaking in an uncertain environment is notably a "learned, non-verbal, domain-specific skill" (Green and Osband, 1991, p. 677), whose practice cannot be replaced by mere verbal explanations. The difference, perhaps, is akin to knowing how an organization works by knowing the people involved as opposed to having access to an organizational chart.

Similar benefits accrue between supervision and the payments-system functions of the central bank. The highly networked nature of payments systems magnifies the risks of individual problems and thus increases the value of information concerning these problems. Detailed knowledge of banks beyond the payments system- how they react to crises, what sort of general operational risk philosophies and 
policies are in place, what bank activities would stress the payments system-benefits the paymentssystem regulator. (This sort of information can also be obtained from general bank supervision.)

The synergy between payments-systems and supervisor functions also provides benefits to supervision. Primarily, these benefits arise because the central bank, in its capacity as monetary authority, will have a better understanding of the macroeconomic context in which the banks operate. While nothing prevents other supervisors from reading the newspapers, they will lack the experience that comes from implementing macroeconomic policy. This external focus on overall conditions, employment, exchange rates, and other risks to the economy provides a perspective that helps the regulator to better gauge the amount of risk the bank allows. As Federal Reserve Board Chairman Alan Greenspan stated in testimony before the Senate Committee on Banking, Housing, and Urban Affairs:

Indeed, a single regulator with a narrow view of safety and soundness and with no responsibility for the macroeconomic implications of its decisions would inevitably have a long-term bias against risk-taking and innovation. It receives no plaudits for contributing to economic growth through facilitating prudent risk-taking, but it is severely criticized for too many bank failures. The incentives are clear. (1994, pp. 130-32)

Because the central bank monitors the reserve and settlement accounts of banks, it gets a real-time view of their liquidity position. Furthermore, as Ralf Pauli puts it (2000, p.19), "being active in the money market, the central bank receives first-hand information on how each bank is perceived by the other market participants." A broader view of bank's needs in the payment area can lead the central bank to be a more effective leader in the payments area. A classic case of this sort of connection arose in 1985: The Fed lent extensively to the Bank of New York via the discount window and its Bank's computer program malfunctioned because the number of treasury securities issued exceeded the program's limit (Green, 2001).

These aspects merge together in the case of financial crises. The primary aim of monetary policy (and payments regulation) then becomes resolution of the crises, and coordination with supervision becomes essential. According to Governor Ferguson:

A Central bank that always must be ready to manage financial crises has to know-at a practical, institutional level—not only how financial markets and institutions operate but also how they are changing and how they are managed.... I shudder to think about crises management with staff without such knowledge and experience... (2000, p. 3000)

This was perhaps best illustrated in the days immediately following the terrorist attacks on September 11, 2001. Governor Ferguson argues that the ability of the Federal Reserve to contain and minimize the damage to the U.S. financial system was enhanced by its firsthand knowledge and experience as a payments-system operator and financial-system supervisor:

The incidents of September 11 taught us many lessons relating to central banking and financial stability. First and foremost, they reinforced the importance of the Federal Reserve's role as lender of last resort. Second, we again saw that the multiple roles the Federal Reserve plays - in this instance, central bank, supervisor and regulator, and payment systems operator-give us many tools to apply during a crisis. While I have been a member of the Board, I have from time to time heard some question the wisdom of our central bank's being involved in supervision and regulation and continuing to provide payment services, particularly retail payment services. To my mind the events of 
September 11 should put such question to rest. From our experience, we should recognize the benefits of a central bank that can influence the economy and enhance financial stability through several mutually reinforcing tools. (Ferguson, 2003)

Although academics and policymakers in the U.S. have hashed out the arguments for and against housing the supervisory function in a central bank, considerably less thought has gone into structuring the organization to maximize the alleged economies of scope. Internal organization has been more of a concern in those countries with newly created consolidated supervisors, such as Britain's Financial Services Authority or Germany's Bundesanstalt fur Finanzdienstleistungsaufsicht (BaFin, for short). Germany provides a particularly instructive example because the relationship between the central bank (Bundesbank) and the BaFin is regulated by Article 7 of the Banking Act and a Memoranda of Understanding between the two organizations. Despite having an independent financial supervisor, the Bundesbank remains directly involved in ongoing prudential supervision, conducting on-site exams for capital adequacy and risk-management practices, in addition to off-site analysis of bank data and reports. The Forum for Financial Market Supervision coordinates the activities of the Bundesbank and the BaFin, in addition to serving as a forum for supervisory issues of joint concern (Schuler, 2004).

Some basic principles for the organizational structure should be clear. The structure must encourage cooperation and communication between the functional supervisors and the umbrella supervisor, perhaps facilitated by reducing overlap between the central bank's supervision and that of the functional regulators. Likewise, if coordination and communication between the banking, payments, and monetary policy branches of the central bank are deemed vital, then these must be encouraged within the organization. A "silo" mentality would be counterproductive. The structure should optimize the information flowing to the key decisionmakers (Sah and Stiglitz, 1986).

\section{Conclusion}

It is clear from the Gramm-Leach-Bliley Act that the Congress, at least for now, has rejected the consolidation of regulatory agencies as an approach for supervising financial holding companies and other types of diverse financial-services firms. Not only was the British Financial Services Authority model rejected for the United States, but there also has been little legislative appetite for consolidating depository-institution regulators at the Federal level. ${ }^{18}$ Instead, GLBA vests the Federal Reserve with responsibility of umbrella supervisor for financial holding companies. It does not, however, extend the Federal Reserve's supervisory authority to other large diversified financial companies, leaving oversight responsibility of thrifts holding companies with the Office of Thrift Supervision and investment bank holding companies with the SEC. Equally important, GLBA preserves the functional-regulator approach by limiting the Federal Reserve's ability to de facto regulate functionally regulated subsidiaries of financial holding companies. Because regulation of financial markets and firms remains fragmented in the face of increasing integration of activities at the firm level, it is clear that some form of consolidated oversight, such as umbrella supervision, is needed, and the Federal Reserve System is just the organization to assume the role.

18. Notably, even consolidation of the Office of Thrift Supervision into the Office of the Comptroller of the Currency is not actively under consideration, despite both agencies being housed within the United States Treasury Department (GA0 2004). 


\section{References}

Walter Bagehot. 1874. Lombard Street: A Description of the Money Market. London: Scribner, Armstrong \& Co.

George J. Benston, Robert A. Eisenbeis, Paul M. Horvitz, Edward J. Kane, and George G. Kaufman. 1986. Perspectives on Safe \& Sound Banking: Past, Present and Future. Cambridge, MA: MIT Press.

Ben S. Bernanke and Mark Gertler. 1990. "Financial Fragility and Economic Performance," Quarterly Journal of Economics, vol. 105, no. 1, 87-114.

Ben S. Bernanke and Mark Gertler. 1995. "Inside the Black Box: The Credit Channel of Monetary Policy Transmission,” Journal of Economic Perspectives, vol. 9, no. 4, 27-48.

Susan Schmidt Bies. 2004a. "Enterprise Perspectives in Financial Institution Supervision." Remarks at the University of Connecticut School of Law, Connecticut Law Review Symposium, Hartford, Connecticut, October 21.

Susan Schmidt Bies. 2004b. "Using Enterprise-wide Risk Management to Effectively Execute Business Strategies." Remarks at the Risk Management Association and Consumer Bankers Association Retail Risk Conference, Chicago, Illinois, July 16.

O. Emre Ergungor. 2003. "Market- vs. bank-based financial systems: Do rights and regulations really matter?" Journal of Banking and Finance, vol. 28, December, 2869-87.

Federal Deposit Insurance Corporation (FDIC). 1998. Managing the Crisis: The FDIC and RTC Experience: Chronological Overview, http://www.fdic.gov/bank/historical/managing/Chron/ index.html (accessed 01/04/05).

R.J. Feldman, J. Kim, P.J. Miller, and J.E. Schmidt. 2003. "Are bank supervisory data useful for macroeconomic forecasts?” Contributions to Macroeconomics, vol. 3, no. 1, Article 3.

Roger W. Ferguson Jr. 2000. "Alternative Approaches to Financial Supervision and Regulation.” Journal of Financial Services Research. Additional citation details for this paper are unclear. The journal is bound as 1999 , vol. 16 , no. $2 / 3$, but the pages list it as 2000 , vol. 17 , no. 1 . The pages on the top of the page run from 297-303, but on the bottom run from 207-13.

Roger W. Ferguson Jr. 2003. “September 11, the Federal Reserve, and the Financial System." Remarks at Vanderbilt University, Nashville, Tennessee, February 5.

Milton Friedman and Anna Jacobson Schwartz. 1963. A Monetary History of the United States, 1867-1960, National Bureau of Economic Research, Studies in Business Cycles. Princeton: Princeton University Press.

Charles A.E. Goodhart. 2000. "The Organisational Structure of Banking Supervision,” FSI Occasional Papers, No. 1, November.

C.A.E. Goodhart and D. Schoenmaker. 1992. "Institutional Separation Between Supervisory and Monetary Agencies," Giorn. Econ. 9-12, 353-439.

Edward J. Green. 2001. "Central Banking and the Economics of Information," Federal Reserve Bank of Chicago, Economic Perspectives, Q2, 28-37. 
Edward J. Green and Kent Osband. 1991. "A Revealed Preference Theory for Expected Utility,” Review of Economic Studies, vol. 58, no. 4, 677-96.

Edward J. Green and Richard M. Todd. 2001. "Thoughts on the Fed's Role in the Payments System," Federal Reserve Bank of Minneapolis, Quarterly Review, vol. 25, no. 1, 12-27.

Alan Greenspan. 1994. "The Views of the Board of Governors of the Federal Reserve on the Consolidation of Bank Supervision and Regulation." Banking Industry Regulatory Consolidation Hearings before the Committee on Banking, Housing, and Urban Affairs. U.S. Senate, S. Hrg., 103-692, 130-56.

Joseph G. Haubrich. 1996. “Combining Bank Supervision and Monetary Policy,” Federal Reserve Bank of Cleveland, Economic Commentary, November.

Joseph G. Haubrich and Joao A.C. Santos. 2003. "Alternative Forms of Mixing Banking with Commerce: Evidence from American History," Financial Markets, Institutions \& Instruments, vol. 12, no. 2, 121-64.

Vasso P. Ioannidou. 2005. “Does Monetary Policy Affect the Central Bank's Role in Bank Supervision?” Journal of Financial Intermediation, vol. 14, 58-85.

Anil K. Kashyap and Jeremy C. Stein. 2000. "What Do a Million Observations on Banks Say About the Transmission of Monetary Policy?” American Economic Review, vol. 90, no. 3, 407-28.

Jonathan R. Macey, Geoffrey P. Miller, and Richard Scott Carnell. 2001. Banking Law and Regulation, New York, NY: Aspen Law \& Business.

Ralf Pauli. 2000. "Payments Remain Fundamental for Banks and Central Banks," Bank of Finland, Discussion Paper, no. 6.

Joe Peek, Eric S. Rosengren, and Geoffrey M.B. Tootell. 1999. "Using Bank Supervisory Data to Improve Macroeconomic Forecasts," New England Economic Review, September/October.

Raghuram G. Rajan and Luigi Zingales. 1998. "Financial Dependence and Growth," American Economic Review, vol. 88, June, 559-86.

Richard J. Rosen. 2003. "Is Three a Crowd? Competition Among Regulators in Banking," Journal of Money, Credit and Banking, vol. 35, no. 6, 967-98.

Raj K. Sah and Joseph E. Stiglitz. 1986. "The Architecture of Economic Systems: Hierarchy and Polyarchy," American Economic Review, vol. 76, 716-27.

Joao A.C. Santos. 1998. "Securities Activities of Banking Conglomerates: Should They Be Regulated?" Cato Journal, vol. 98, Spring/Summer, 93-108.

Martin Schuler. 2004. "Integrated Financial Supervision in Germany," Centre for European Economic Research, Discussion paper no. 04-35.

Edward J. Stevens. 1996. "The Founders' Intentions: Sources of the Payment Services Franchise of the Federal Reserve Banks,” Financial Services Research Group Working Paper 03-96. December.

United States General Accounting Office (GAO). 2004. "Financial Regulation: Industry Changes Prompt Need to Reconsider U.S. Regulatory Structure," Report to the Chairman, Committee on Banking, Housing, and Urban Affairs, U.S. Senate, October.

Ed Young. 1993. Seven Blind Mice, New York, NY: Philomel Books. 


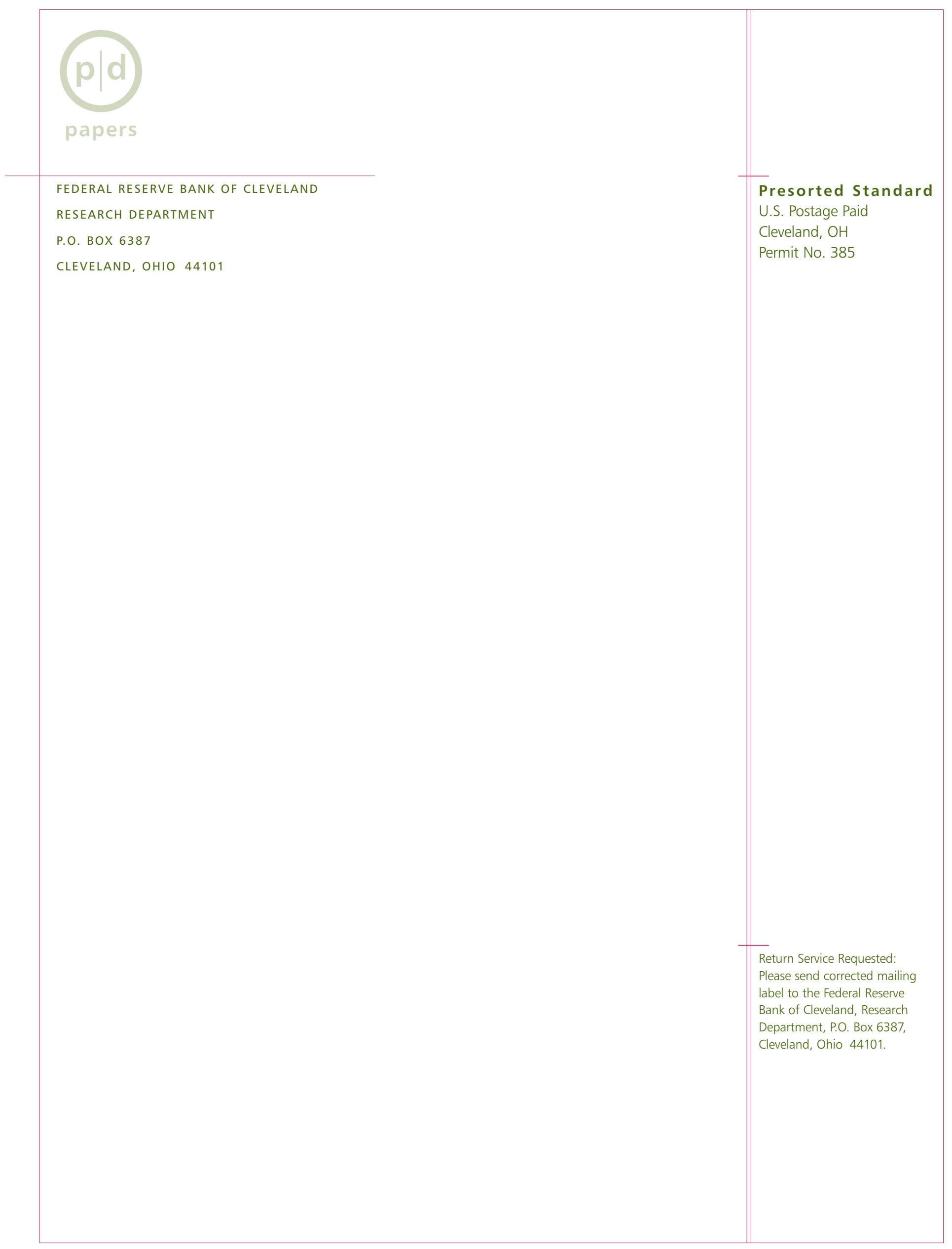

